\title{
Evaluation of Anemia and Hematological Parameters in Antenatal
}

\author{
Khetrapal Shaan, Jairajpuri S Zeeba, Rana Safia*, Jetley Sujata
}

Department of Pathology, Hamdard Institute of Medical Sciences and Research, Jamia Hamdard, Hamdard Nagar, New Delhi INDIA

\begin{abstract}
Background: Anemia is one of the most commonly encountered medical disorders during pregnancy. The haematological profile have both an impact on pregnancy as well as its outcome. The hematologic status in a pregnant woman can be evaluated by measuring different blood indices such as haemoglobin concentration, packed cell volume (PCV), red blood cell count, total WBC count etc. The present study was undertaken to monitor haematological parameters during antenatal visits and the ability to predict and /or improve pregnancy outcome, with the help of hematological parameters.

Methods: The present study is a cross sectional study comprising of 173 pregnant females attending the antenatal care of the Department of Obstetric and Gynaecology

Result: Among the 173 pregnant females, majority $44.50 \%$ had mild anemia with hemoglobin levels between $10-10.9 \mathrm{gm} / \mathrm{dl}$ while moderate anaemia was seen in $42.19 \%$ of patients. However severe anemia was seen in $13.29 \%$ patients.

Conclusion: The hematological status in pregnant women can be evaluated by measuring different hematological parameters and indices. $\mathrm{RBC}$ count is one of the important indications of anemia and indices like $\mathrm{MCV}, \mathrm{MCH}, \mathrm{MCHC}$ provide information about the hemoglobin content and size of blood cells which are useful in typing of anemia. The need of the hour is to monitor the various hematological parameters during pregnancy as anemia has very deleterious effects on both mother and fetus and is an easily preventable cause.
\end{abstract}

Keywords: Anemia, Antenatal, Hematological, Pregnancy

\section{Introduction}

Hematological profile is not only a reflection but also a reliable indicator of general health along with being a simple, fast and cost-effective test. ${ }^{[1]}$ The pregnant state induces many changes in a woman amongst those seen in the haematological profile are important which not only has an impact on pregnancy but also its outcome. The hematologic status in a pregnant woman can be evaluated by measuring different blood indices such as haemoglobin concentration, packed cell volume (PCV), red blood cell count, total white blood cell count and differential count amongst others. Anemia is one of the most commonly encountered medical disorders during pregnancy defined by decreased hemoglobin level or circulating red blood cells. In developing countries prevalence is high leading to various adverse effects on the mother and the fetus causing high maternal mortality and foetal complications. It is one of the most common preventable causes of maternal morbidity and poor perinatal outcome. The main causes of anemia during pregnancy involve deficiencies of nutrients, infections, and parasitic diseases. Amongst the many factors that influence pregnancy some of which include culture, environment, socioeconomic status, and access to medical care, the impact of haematological indices on pregnancy and its outcome is significant. ${ }^{[2]}$ Anaemia is known to contribute to intrauterine growth retardation, preterm labour, abortions alongwith primary cause of low immunity of both the mother and baby, making them prone for infections. ${ }^{[3]}$. Assigning a normal reference range for haemoglobin concentration during pregnancy is difficult. According to the standard laid down by WHO, anemia in pregnancy is present when the haemoglobin concentration in the peripheral blood is $11 \mathrm{gm} / 100 \mathrm{ml}$ or less. ${ }^{[3]}$ According to United Nation declaration 1997, anemia is a major public health problem requiring total elimination. It is estimated that globally about two billion people suffer from anemia or iron deficiency. ${ }^{[4]}$

The importance of monitoring haematological parameters during antenatal care lies in the ability to predict and /or improve pregnancy outcome, with this in mind the present study was undertaken.

\section{Materials and Methods}

A total of 173 pregnant female patients attending antenatal clinic, were analyzed in this study. All relevant data related to the patient's clinical presentation were collected. Venous blood samples were drawn from pregnant women attending antenatal clinic for the assessment of hematological parameters. EDTA tubes were used for adequate blood sample collection. The samples were analysed on three-part 
auto analyzer for parameters including $\mathrm{Hb}$ concentration, $\mathrm{PCV}, \mathrm{RBC}$ concentration, $\mathrm{MCH}, \mathrm{MCV}, \mathrm{MCHC}, \mathrm{WBC}$ count, and Platelet count. Standardization and calibration of the instrument, and processing of the samples were done according to instructions.

\section{Result}

The present study is a cross sectional study comprising of 173 pregnant females attending the antenatal care of the Department of Obstetric and Gynaecology, with haemoglobin less than $11 \mathrm{gm} / \mathrm{dl}$. Age wise distribution of the patients showed a maximum of $53.2 \%$ cases in the age group 20-25 yrs followed by $35.8 \%$ in the age group 26-30 years. Out of the 173 pregnant females majority $44.50 \%$ had mild anemia with $\mathrm{Hb}$ between $10-10.9 \mathrm{gm} / \mathrm{dl}$ while moderate anaemia was seen in $42.19 \%$ of patients and severe anemia was seen in $13.29 \%$ patients. (Table 1 )

The hematologic status in pregnant women can be evaluated by measuring different blood parameter of which red blood cell count is an important indication of anemia. Red blood cell count was decreased ( $<4$ million / cumm) in $87.2 \%$ of our patients. However normal RBC counts was seen in $10.9 \%$ cases while an increased $\mathrm{RBC}$ count was seen in $1.73 \%$ of the patients. (Table 2)

Blood indices i.e Mean Corpuscular Volume (MCV, normal range 80-100 fL), Mean corpuscular haemoglobin $(\mathrm{MCH}$, Normal range: 27-31 pg/cell) and Mean Corpuscular
Hemoglobin Concentration (MCHC, Normal range: 32$36 \mathrm{~g} / \mathrm{dl}$ ) were also calculated and evaluated in the present study group. (Table.3) These indices provide information about the hemoglobin content and size of red blood cells. Abnormal values indicate not just the presence of anemia but also type of anemia. MCV was found to be below normal range in majority of the patients $(71 \%)$.

On further analyzing, the cases were classified into type of anemia on peripheral blood examination. In our study majority of the patients suffered from microcytic hypochromic $(123,71.1 \%)$ while dimorphic anemia was seen in 14 patients $(8.1 \%)$ indicating nutritional deficiencies. Distribution of cases according to age with their respective haematological parameters are depicted in Table 4 with the mean of each parameter

Religious and cultural beliefs often have a major bearing on the eating habits of women in our country.Keeping this in mind we also analyzed the haematological profile of these pregnant females according to their religious beliefs. Out of the 173 patients who formed the study group, 120 were Hindus and 53 were Muslims. The prevalence of anemia was more in pregnant females with Hindu beliefs as compared to Muslim patients.

\section{Discussion}

Hematological abnormalities, especially anemia, may have adverse impact on pregnancy outcome and in most

Table 1: Distribution According To The Degree Of Severity Of Anemia.

\begin{tabular}{|c|c|c|}
\hline Anemia & No. of patients $(n=173)$ & Percentage (\%) \\
\hline Mild anemia $(10-10.9 \mathrm{gm} / \mathrm{dl})$ & 77 & 44.50 \\
\hline Moderate anemia $(7-9.9 \mathrm{gm} / \mathrm{dl})$ & 73 & 42.19 \\
\hline Severe anemia $(<7 \mathrm{gm} / \mathrm{dl})$ & 23 & 13.29 \\
\hline Total & 173 & 100 \\
\hline
\end{tabular}

Table 2: Distribution according to red blood cell count in pregnant women.

\begin{tabular}{|c|c|c|}
\hline RBC count & No. of Patients & Percentage \\
\hline Normal $(4.0-5.2$ million/cumm) & 19 & 87.2 \\
\hline Decreased $(<4.0$ million/cumm) & 151 & 1.7 \\
\hline Increased $(>5.2$ million/cumm) & 3 & 100 \\
\hline Total & 173 & 10.9 \\
\hline
\end{tabular}

Table 3: Distribution of cases according to Red blood Cell indices.

\begin{tabular}{|c|c|c|c|}
\hline RBCIndices & Below normal range & Within Normal Range & Above Normal Range \\
\hline MCV (fl) & 123 & 47 & 3 \\
\hline MCH $(\mathrm{pg})$ & 119 & 51 & 3 \\
\hline $\mathrm{MCHC}(\mathrm{g} \%)$ & 126 & 47 & - \\
\hline
\end{tabular}


Table 4: Type of anemia in pregnant women.

\begin{tabular}{|c|c|c|}
\hline Type of anemia & No. of patients & 11.5 \\
\hline Normocytic \& normochromic & 20 & 71.1 \\
\hline Microcytic hypochromic & 123 & 7.5 \\
\hline Normocytic \& hypochromic & 13 & 8.1 \\
\hline Microcytic \& macrocytic (Dimorphic) & 14 & 1.7 \\
\hline Macrocytic & 3 & 100 \\
\hline Total & 173 & 100 \\
\hline
\end{tabular}

Table 5: Blood Parameters according to age group.

\begin{tabular}{|c|c|c|c|c|c|c|c|c|}
\hline $\begin{array}{c}\text { Age Group } \\
\text { (years) }\end{array}$ & $\begin{array}{c}\text { No. of } \\
\text { Patients }\end{array}$ & $\begin{array}{c}\text { Hemoglobin } \\
\text { Mean } \pm \text { SD }\end{array}$ & $\begin{array}{c}\text { RBC } \\
\text { Mean } \pm \text { SD }\end{array}$ & $\begin{array}{c}\text { PCV } \\
\text { Mean } \pm S D\end{array}$ & $\begin{array}{c}\text { MCV } \\
\text { Mean } \pm S D\end{array}$ & $\begin{array}{c}\text { MCH } \\
\text { Mean } \pm S D\end{array}$ & $\begin{array}{c}\text { MCHC } \\
\text { Mean } \pm S D\end{array}$ & $\begin{array}{c}\text { RDW } \\
\text { Mean } \pm S D\end{array}$ \\
\hline$<19$ & 9 & $8.84 \pm 1.24$ & $3.97 \pm 0.34$ & $32.86 \pm 3.37$ & $72.94 \pm 8.64$ & $26.63 \pm 3.43$ & $32.04 \pm 1.54$ & $29.67 \pm 3.4$ \\
\hline $20-25$ & 92 & $9.83 \pm 1.60$ & $3.91 \pm 0.51$ & $33.00 \pm 4.29$ & $74.58 \pm 7.27$ & $26.94 \pm 2.99$ & $31.70 \pm 1.92$ & $20.02 \pm 2.8$ \\
\hline $26-30$ & 62 & $10.63 \pm 1.69$ & $3.93 \pm 0.50$ & $33.00 \pm 4.20$ & $78.18 \pm 7.10$ & $27.10 \pm 3.18$ & $32.26 \pm 1.97$ & $15.2 \pm 1.3$ \\
\hline $31-35$ & 8 & $8.23 \pm 1.84$ & $3.37 \pm 0.58$ & $32.6 \pm 4.794$ & $75.06 \pm 6.18$ & $26.61 \pm 2.75$ & $31.57 \pm 1.49$ & $21.2 \pm 2.3$ \\
\hline$>35$ & 2 & $9.31 \pm 1.13$ & $3.63 \pm 0.21$ & $32.80 \pm 2.82$ & $71 \pm 9.47$ & $20.1 \pm 3.39$ & $28.30 \pm 0.98$ & $19.1 \pm 2.2$ \\
\hline
\end{tabular}

Table 6: Blood Parameters According To Religion.

\begin{tabular}{|c|c|c|}
\hline Haematological Parameter (Mean \pm SD) & Hindu & Muslim \\
\hline Hemoglobin & $8.2 \pm 1.5$ & $3.9 \pm 1.4$ \\
\hline Red Blood Cell Count & $3.35 \pm 0.50$ & $32.8 \pm 4.2$ \\
\hline Packed Cell Volume & $33.4 \pm 3.9$ & $74 \pm 5.9$ \\
\hline Mean Corpuscular Volume & $73.8 \pm 7.1$ & $26.8 \pm 2.7$ \\
\hline Mean Corpuscular Haemoglobin & $26.7 \pm 2.9$ & $31.8 \pm 0.8$ \\
\hline Mean Corpuscular Hemoglobin Concentration & $31.8 \pm 1.6$ & $17.2 \pm 10.3$ \\
\hline
\end{tabular}

Table 7: Blood Parameters in comparison to non pregnant females.

\begin{tabular}{|c|c|c|}
\hline Haematological Parameter (Mean \pm SD) & Non Pregnant Females & Pregnant Females \\
\hline Hemoglobin & $10.5 \pm 2.6$ & $10.6 \pm 1.6$ \\
\hline Red Blood Cell Count & $3.8 \pm 0.9$ & $3.9 \pm 0.5$ \\
\hline Packed Cell Volume & $33.2 \pm 7.6$ & $84.1 \pm 7.3$ \\
\hline Mean Corpuscular Volume & $86.5 \pm 9.8$ & $26.8 \pm 3.1$ \\
\hline Mean Corpuscular Haemoglobin & $27.3 \pm 4.2$ & $31.8 \pm 1.9$ \\
\hline Mean Corpuscular Hemoglobin Concentration & $31.5 \pm 2.1$ & $39.9 \pm 15.4$ \\
\hline
\end{tabular}


Table 8: The findings of various studies of blood parameters according to age group(Table 5) are compared in a tabular form.

\begin{tabular}{|c|c|c|c|c|c|c|c|c|c|c|c|c|c|c|}
\hline \multirow[t]{2}{*}{$\begin{array}{l}\text { Age } \\
\text { Group } \\
\text { (year) }\end{array}$} & \multicolumn{2}{|c|}{ No. of Patients } & \multicolumn{2}{|c|}{$\begin{array}{l}\text { Hemoglobin } \\
\text { Mean } \pm S D\end{array}$} & \multicolumn{2}{|c|}{$\begin{array}{c}\text { RBC } \\
\text { Mean } \pm S D\end{array}$} & \multicolumn{2}{|c|}{$\begin{array}{c}\text { PCV } \\
\text { Mean } \pm S D\end{array}$} & \multicolumn{2}{|c|}{$\begin{array}{c}\text { MCV } \\
\text { Mean } \pm S D\end{array}$} & \multicolumn{2}{|c|}{$\begin{array}{c}\text { MCH } \\
\text { Mean } \pm S D\end{array}$} & \multicolumn{2}{|c|}{$\begin{array}{c}\text { MCHC } \\
\text { Mean } \pm \text { SD }\end{array}$} \\
\hline & $\begin{array}{c}\text { Present } \\
\text { study }\end{array}$ & $\begin{array}{l}\text { Swati } \\
\text { Singh } \\
\text { et } \mathrm{al}^{\mathrm{K}}\end{array}$ & $\begin{array}{l}\text { Present } \\
\text { study }\end{array}$ & $\begin{array}{c}\text { Swati } \\
\text { Singh et } \\
\text { al }^{\mathrm{K}}\end{array}$ & $\begin{array}{c}\text { Present } \\
\text { study }\end{array}$ & $\begin{array}{l}\text { Swati } \\
\text { Singh } \\
\text { et } \mathrm{al}^{\mathrm{K}}\end{array}$ & $\begin{array}{l}\text { Present } \\
\text { study }\end{array}$ & $\begin{array}{c}\text { Swati } \\
\text { Singh et } \\
\text { al }^{\mathrm{K}}\end{array}$ & $\begin{array}{l}\text { Present } \\
\text { study }\end{array}$ & $\begin{array}{l}\text { Swati } \\
\text { Singh } \\
\text { et alk }\end{array}$ & $\begin{array}{l}\text { Present } \\
\text { study }\end{array}$ & $\begin{array}{l}\text { Swati } \\
\text { Singh } \\
\text { et } \mathrm{al}^{\mathrm{K}}\end{array}$ & $\begin{array}{c}\text { Present } \\
\text { study }\end{array}$ & $\begin{array}{l}\text { Swati } \\
\text { Singh } \\
\text { et } a^{\mathrm{K}}\end{array}$ \\
\hline$<19$ & 9 & 3 & & $\begin{array}{l}8.6 \pm \\
2.08\end{array}$ & & $\begin{array}{c}3.23 \pm \\
0.06\end{array}$ & $\begin{array}{c}32.86 \pm \\
3.37\end{array}$ & $\begin{array}{c}30.2 \pm \\
7.93\end{array}$ & $\begin{array}{c}72.94 \pm \\
8.64\end{array}$ & & $\begin{array}{c}26.63 \pm \\
3.43\end{array}$ & $\begin{array}{c}26.9 \pm \\
1.1\end{array}$ & $\begin{array}{c}32.04 \pm \\
1.54\end{array}$ & $\begin{array}{c}30.06 \pm \\
1.68\end{array}$ \\
\hline $20-25$ & 92 & 50 & $\begin{array}{c}9.83 \pm \\
1.60\end{array}$ & $\begin{array}{c}8.08 \pm \\
1.46\end{array}$ & $\begin{array}{c}3.91 \pm \\
0.51\end{array}$ & $\begin{array}{c}3.46 \pm \\
0.86\end{array}$ & $\begin{array}{c}33.00 \pm \\
4.29\end{array}$ & $\begin{array}{c}28.73 \pm \\
4.84\end{array}$ & $\begin{array}{c}74.58 \pm \\
7.27\end{array}$ & $\begin{array}{c}76.45 \pm \\
8.78\end{array}$ & $\begin{array}{c}26.94 \pm \\
2.99\end{array}$ & $\begin{array}{c}27.4 \pm \\
2.57\end{array}$ & $\begin{array}{c}31.70 \pm \\
1.92\end{array}$ & $\begin{array}{c}30.89 \pm \\
2.15\end{array}$ \\
\hline $26-30$ & 62 & 19 & 10.63 & \begin{tabular}{|c|}
$7.983 \pm$ \\
1.48 \\
\end{tabular} & $\begin{array}{c}3.93 \pm \\
0.50\end{array}$ & $\begin{array}{c}3.29 \pm \\
0.66 \\
\end{array}$ & $\begin{array}{c}33.00 \pm \\
4.20 \\
\end{array}$ & $\begin{array}{c}30.3 \pm \\
6.64 \\
\end{array}$ & $\begin{array}{c}78.18 \pm \\
7.10 \\
\end{array}$ & $\begin{array}{c}80.65 \pm \\
8.77 \\
\end{array}$ & $\begin{array}{c}27.10 \pm \\
3.18 \\
\end{array}$ & $\begin{array}{r}27.67 \\
\pm 2.91 \\
\end{array}$ & \begin{tabular}{|c|}
$32.26 \pm$ \\
1.97 \\
\end{tabular} & $\begin{array}{c}30.99 \pm \\
2.46\end{array}$ \\
\hline $31-35$ & 8 & 8 & $\begin{array}{c}8.23 \pm \\
1.84\end{array}$ & $\begin{array}{c}8.18 \pm \\
1.76\end{array}$ & $\begin{array}{c}3.37 \pm \\
0.58\end{array}$ & $\begin{array}{c}3.25 \pm \\
0.27\end{array}$ & $\begin{array}{l}32.6 \pm \\
4.794\end{array}$ & $\begin{array}{c}33.9 \\
\pm 7.02\end{array}$ & $\begin{array}{c}75.06 \pm \\
6.18\end{array}$ & $\begin{array}{c}85.36 \pm \\
11.61\end{array}$ & $\begin{array}{c}26.61 \pm \\
2.75\end{array}$ & $\begin{array}{c}28.0 \pm \\
2.88\end{array}$ & $\begin{array}{c}31.57 \pm \\
1.49\end{array}$ & $\begin{array}{c}32.38 \pm \\
0.78\end{array}$ \\
\hline
\end{tabular}

developing countries makes an important contribution to maternal mortality and morbidity, adding to the already stretched resources of these countries ${ }^{[5]}$ According to the World Health Organization estimates, up to $56 \%$ of all women living in developing countries are anemic, as per its guidelines, hemoglobin level below $11 \mathrm{gm} / \mathrm{dl}$ in pregnant women constitutes anemia while that below $7 \mathrm{gm} /$ $\mathrm{dl}$ is severe anemia. ${ }^{[6]}$ The WHO definition for diagnosis of anemia in pregnancy is a $\mathrm{Hb}$ concentration of less than 11 $\mathrm{g} / \mathrm{dl}(7.45 \mathrm{mmoL} / \mathrm{L})$ and a hematocrit of less than $33 \%{ }^{[6]}$

Anemia is the most common hematological disorder seen in pregnancy, as is well known pregnancy is influenced by many factors, some of which include culture, environment, socioeconomic status, education and access to medical care. In India, the statistics is almost the same, the National Family Health Survey -2 in 1999 shows that 54\% of women in rural and $46 \%$ women in urban areas are anemic. The Center for Disease Control and Prevention (1990) defines anemia as less than $11 \mathrm{gm} / \mathrm{dl}$ in the first and third trimester and less than $10.5 \mathrm{gm} / \mathrm{dl}$ in second trimester. ${ }^{[7,8]}$. In this study, the prevalence of anemia in pregnant women was significantly high having $100 \%$ of pregnant females fall into the category. These findings were in concordance with the study conducted in Jaipur. ${ }^{[9]}$ However as stated by Suryanarayana et al, the prevalence of anemia in pregnant women was $64 \%$ a study conducted in Karnataka and a higher prevalence was observed in studies of Ahmad et al and Kaul et al. being $74.8 \%$ and $91 \%$ respectively ${ }^{[10]}$

The mean hemoglobin level of pregnant women in this study was found to be $10.6 \pm 1.6$ which was similar to studies of Suryanarayana et al and Bisoi et al having $10.3 \pm 1.53 \mathrm{~g} \%$, and $10.1 \pm 0.98 \mathrm{~g} \%$ respectively. ${ }^{[10]}$ Out of the 173 pregnant females majority $44.50 \%$ had mild anemia with hemoglobin levels between $10-10.9 \mathrm{gm} / \mathrm{dl}$ while moderate anaemia was seen in $42.19 \%$ of patients. However severe anemia was seen in $13.29 \%$ patients. (Table 1) These findings are comparable with the studies conducted by Suryanarayana et al where the prevalence of mild, moderate, and severe anemia were observed as $27 \%, 34 \%$, and $3 \%$, respectively. [10] Various other studies conducted by Sharma et al[9] in Rajasthan and by Wadgav HV. Mondal et al. reported that majority of the anemic women belonged to moderate anemia $(91.46 \%)^{[10]}$ whereas in our study majority of the females had mild anemia comprising $44.5 \%$ and $42.1 \%$ had moderate anemia. Findings of severe anemia were variable ranging from $0.6 \%$ in a study by Kumar et al ${ }^{[11]}$ to $18.9 \%$ in a study by Ahmed et $\mathrm{al}^{[12]}$ which are comparable to our findings of $13.29 \%$.

The higher prevalence of anemia in our study can be attributed to low socio economic group, non-availability or failure to utilize available medical facilities by females visiting the antenatal clinics, nutritional deficiencies like low dietary iron and folic acid intake and/or low bioavailability of iron along with any infections leading to chronic blood loss.

Various haematological changes take place during pregnanacy. Physiological anaemia is often attributed to increase in plasma volume, RBC volume and haemoglobin mass in cases of pregnant ladies. Expansion of plasma volume leads to RBC mass dilution resulting in physiological anemia of pregnancy. ${ }^{[13]}$ These include, increases in plasma volume of $25 \%-80 \%$ between the sixth and twenty-fourth week of gestation. ${ }^{[14]}$,increase in $\mathrm{RBC}$ mass approximately $30 \%$ between the twelfth and thirty-sixth week of gestation when iron and folate are supplemented ${ }^{[15]}$ The discrepancy between the rate of increase in plasma volume and that in RBC mass leads to physiological anemia. In late pregnancy, plasma volume increases at a slower rate, inducing a slight rise in hematocrit level. These physiological changes during pregnancy make it difficult to define normal hematological reference intervals for pregnant women. ${ }^{[1]}$ 
The hematological status in pregnant women can be evaluated by measuring different blood parameters and blood indices. Red blood cell count is one of the important indications of anemia and blood indices like $\mathrm{MCV}, \mathrm{MCH}$, MCHC provide information about the hemoglobin content and size of blood cells which are useful in typing of anemia. The RBC count was decreased in majority of our study group constituting $87.2 \%$ with $10.9 \%$ in normal range while $1.7 \%$ females had an increased RBC count (Table 2). Singh et $\mathrm{al}^{[15]}$ found $67.5 \%$ women with below normal range $\mathrm{RBC}$ count, similar findings of majority females having low RBC count was found in study by Sharma et

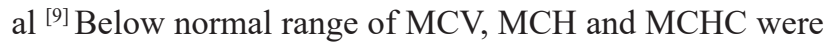
found in 123, 119 and 126 pregnant women respectively. (Table 3) Similar findings were seen in a study by Shah et al where $\mathrm{MCV}$ was below normal range in $70.6 \%$ females as compared to our $71 \%$, while $\mathrm{MCH}$ was below normal level in $58.9 \%$ pregnant women which is less as compared to our study. ${ }^{[16]}$ However contrasting findings were seen in a study by Dhaliwal et al where there was no significant change in MCVvalues, on the other hand, MCHC and MHC showed significant decrease in pregnant women. ${ }^{[17]}$

On further analyses five types of anemia were seen in anemic women based on peripheral blood examination as shown in Table 4. In our study majority of the pregnant women suffered from microcytic hypochromic anemia (71.1\%), followed by $11.5 \%$ normocytic normochromic while dimorphic anemia was seen in $8.1 \%$ women, $7.5 \%$ had normocytic hypochromic and a miniscule of $1.7 \%$ had macrocytic picture. These findings are comparable to a study conducted by Singh et al where also the majority cases were of microcytic \& hypochromic $47.5 \%$, followed by normocytic \& hypochromic $32.5 \%$, normocytic \& normochromic $6.25 \%$, dimorphic $7.5 \%$ and macrocytic anemia $6.25 \%$. ${ }^{[15]}$

The findings of various studies of blood parameters according to age group(Table 5) are compared in a tabular form and findings are found to be in concordance to our study.

The prevalence of anemia was more in pregnant females with Hindu beliefs as compared to Muslim patients (Table 6) in our study and the same findings were seen in Sharma et al [9] study.

\section{Effects of Anaemia on Pregnancy}

Maternal effects ${ }^{[18,19]}$ Mild, anemia may not have any effect on pregnancy and labour except low maternal iron stores and may become moderate to-severely anemic in subsequent pregnancies. Moderate anemia may cause increased weakness, lack of energy, fatigue and poor work performance. Severe anemia, however, is associated with poor outcome. Common symptoms like palpitations, tachycardia, breathlessness, increased cardiac output leading on to cardiac stress which can cause decompensation and cardiac failure which can be fatal ${ }^{[12]}$. Increased incidence of pre-term labour (28.2\%), preeclampsia (31.2\%) and sepsis have been associated with anemia [19]

Fetal effects ${ }^{[18]}$ Irrespective of maternal iron stores, the fetus still obtains iron from maternal transferrin, which is trapped in the placenta and which, in turn, removes, and actively transports iron to the fetus. In these cases, subsequently however, such fetuses tend to have decreased iron stores due to depletion of maternal stores. Adverse perinatal outcome in the form of pre-term and small-forgestational-age babies and increased perinatal mortality rates have been observed in the neonates of anemic mothers. Iron supplementation to the mother during pregnancy improves perinatal outcome. Mean weight, Apgar score and haemoglobin level 3 month after birth were significantly greater in babies of the supplemented group.

\section{Conclusion}

The need of the hour is to monitor the various hematological parameters during pregnancy as anemia has very deleterious effects on both mother and fetus and is an easily preventable cause. In the developing countries with availability and access to medical care still having huge number of anemic pregnant females points towards the indifference and ignorance to health needs. Therefore, strategic efforts are needed to not just broaden the coverage of iron and folic acid distribution and its consumption but an urgent need to counsel and educate about the importance of antenatal care to pregnant women and their families. To fight this menace health education on reproductive health is the foremost step and subsequently the monitoring of compliance of antenatal care are the most important health care measures to be taken urgently and at all levels.

\section{Reference}

1. Shen C, Jiang YM, Shi H, Liu JH, Zhou WJ, Dai QK, Yang $H$. A prospective, sequential, and longitudinal study of haematological profile during normal pregnancy in Chinese women. J Obstet Gynaecol. 2010;30:357-61.

2. Chaudhari SJ, BodatisepK. Tracking Of Haematological Parameters In First And Second Trimester Of Pregnancy. NJMR 2015;5:259-61

3. Das S, Char D, Sarkar S, Saha TK, Biswas S. Study of Hematological Parameters in Pregnancy JDMS 
4. UNICEF and Micronutrient Initiative. Vitamin and mineral deficiency: a global progress report March 2004.

5. Focussing on anemia: Towards an integrated approach for effective anemia control. Joint statement by the world Health Organization and the United National Children's Fund. World Health Organization..2004, anaemia statement. pdf. May 10, 2007

6. World Health Organization .The prevalence of anemia in women: A Tabulation of Available Information; second edition .Geneva: WHO, 1992. (WHO/MCH/MSM/92.2).

7. World Health Organization .The prevalence of anemia in women: A Tabulation of Available Information; second edition .Geneva: WHO, 1992. (WHO/MCH/MSM/92.2).

8. Centers for disease Control,Criteria for anemia in children and childbearing aged women .MMWR 1989;38:400-4.

9. Sharma P, Nagar R. Hematological profile of anemic pregnant women attending antenatal hospital. IOSR Journal of Nursing and Health Science 2013; 1:11-15.

10. Suryanarayana R, Santhuram AN, Chandrappa M, Shivajirao P, Rangappa SS. Prevalence of anemia among pregnant women in rural population of Kolar district. Int J Med Sci Public Health 2016;5:454-58.

11. Ahmad N, Kalakoti P, Bano R, Syed MMA. The prevalence of anemia and associated factors in pregnant women in rural Indian community. Australas Med J 2010;3:276-80.
12. WHO, Iron deficiency anemia: assessment, prevention and control .WHO/NHD/ 01.3,Geneva.2001.

13. Sharma JB, Shankar M. Anemia in Pregnancy. JIMSA 2010;23:253-60.

14. Lund CJ, Donovan JC. Blood volume during pregnancy. Significance of plasma and red cell volumes. Am J Obstet Gynecol. 1967;98(3): 394-403.

15. Singh $\mathrm{P}$, Singh $\mathrm{S}$, Topesh. Hematological parameters in anaemic pregnant women attending the antenatal clinic of tertiary care hospital. Int J Res Health Sci [Internet]. 2014; 31;2:981-6.

16. Shah AR, Patel ND1, Shah MH. Hematological parameters in anaemic pregnant women attending the antenatal clinic of rural teaching hospital. Innovative Journal of Medical and Health Science 2012;70-3.

17. Dhariwal SK, Narang S, Singh A, Nema S. Evaluation of haematological indices, neutrophils and platelets in pregnant women attending tertiary care centre. Indian Journal of Pathology and Oncology, April-June 2016;3;297-304.

18. Sharma J.B. Nutritional anemia during pregnancy in nonindustrial countries, Progress in Obst. \& Gynae (Studd) 2003;15:103-22.

19. Malhotra M, Sharma JB, Batra S, Sharma S, Murthy NS, Arora R. Maternal and perinatal outcome in varying degrees of anemia. Int J Gynaecol Obstet. 2002;79:93-100.

*Corresponding author:

Dr. Safia Rana, Assistant Professor, Department of Pathology, Hamdard Institute of Medical Sciences and Research, Jamia Hamdard New Delhi 110062.

Email: safia_rana2000@yahoo.com

Financial or other Competing Interests: None. 